\title{
Giant cavernous malformations
}

Cavernous malformations represent about $10 \%$ of all vascular lesions of the brain..$^{[1-3]}$ They occur equally among men and female and usually present between the ages of 20 and 40 years. Cavernous malformations are most commonly located in the cerebral hemispheres, especially in the parietal lobe and thalamus. ${ }^{[4,5]}$ Intracranial extra-axial cavernomas are relatively rare. ${ }^{[6]}$ They are congenital in origin and are differentiated clearly from vascular tumors. As these lesions are essentially nonspace occupying and angiographically occult, the detection rate and the clinical interest in this entity have increased in the era of computer tomography and magnetic resonance (MR) imaging. Cavernous hemangiomas are more often identified as small lesions, which show evidence of hemorrhage. Cavernous malformations can present with headaches, seizures, neurological deficits, or can be found incidentally. The natural history of cavernous malformations has been studied in detail and is still under debate. ${ }^{[7,8]}$ When hemorrhages occur, cavernous malformations have a high risk of rebleeding, with rebleeding rates of, for example, brainstem cavernous malformations ranging from $5 \%$ to $35 \%$ per year.

Although intracranial intra-axial and extra-axial cavernomas are reported, giant intracranial cavernomas are extremely rare. Giant cavernomas are usually found in the gastrointestinal tract, especially in the liver and spleen and also in the subcutaneous region. Giant intracranial extracerebral cavernomas are reported in the scalp, pericranium, pituitary gland, middle cranial fossa, and cavernous sinus. ${ }^{[9-12]}$ Giant intracranial, intraaxial cerebral parenchymal cavernomas are reported in some case reports and reviews as presented in this case.

The relationship between the size of cavernoma and probability of hemorrhage or long-term neurological morbidity is still under debate. However, the growth of intracerebral cavernomas is accentuated by repeated microhemorrhages into the cavernoma. The large size of giant cavernomas, reported in some cases, may be explained on this hypothesis. There might also be a possibility of accelerated growth due to hormonal changes during puberty. The growth of cavernoma over a time period and the correlative MR imaging changes are reported in $38 \%$ of patients. ${ }^{[13]}$ They exhibit a range of dynamic behavior including increase or decrease in size, de novo formation as well as progression through a series of characteristic MR imaging appearances. ${ }^{[13]}$

Surgical intervention is the treatment of choice for all cavernous malformations. ${ }^{[3]}$ Thereby, the localization may be influence the indication und decision for surgery. It is also indicated in patients with hemorrhages which have a cavernoma that presents to the pial surface in eloquent areas or brainstem. Thereby, the surgical approach is dictated by the location of the cavernous malformation and using available microsurgical techniques is ideal since the cavernoma is well circumscribed to the surrounding brain tissue.

The main goal of modern surgical treatment of cavernous malformations is minimizing the amount of healthy tissue that must be traversed to achieve a complete resection. ${ }^{[1,14,15]}$ The risks and benefits of surgical treatment must be weighed against possible morbidity resulting from surgery. Thus and in consequence of modern MR imaging, excellent neuronavigation systems, minimally invasive approaches and new surgical tools surgical resection can be also performed in cavernous malformations localized in eloquent areas ${ }^{[15]}$ and should also be performed in the case of giant cavernous malformations.

In modern neurosurgery, the surgical goal of total resection of giant cavernous malformations without any surgical morbidity should be possible in nearly all cases.

\section{Stefan Linsler}

Department of Neurosurgery, Saarland University, 66421 Homburg, Germany

Address for correspondence:
Dr. med. Stefan Linsler,
Department of Neurosurgery, Saarland University,
66421 Homburg, Germany.
E-mail: stefan.linsler@uks.eu

\section{References}

1. Barrow DL. Intraoperative misadventures: Complication avoidance and management in aneurysm surgery. Clin Neurosurg 2011;58:93-109.

2. Gross BA, Batjer HH, Awad IA, Bendok BR. Cavernous malformations of the basal ganglia and thalamus. Neurosurgery 2009;65:7-18.

3. Sharma A, Mittal RS. A giant frontal cavernous malformation with review of literature. J Neurosci Rural Pract 2016;7:279-82. 
4. Cappabianca P, Spaziante R, de Divitiis E, Villanacci R. Thalamic cavernous malformations. J Neurosurg 1991;75:169-71.

5. Tagle P, Huete I, Méndez J, del Villar S. Intracranial cavernous angioma: Presentation and management. J Neurosurg 1986;64:720-3.

6. Voelker JL, Stewart DH, Schochet SS Jr. Giant intracranial and extracranial cavernous malformation. Case report. J Neurosurg 1998;89:465-9.

7. Moriarity JL, Clatterbuck RE, Rigamonti D. The natural history of cavernous malformations. Neurosurg Clin N Am 1999;10:411-7.

8. Porter PJ, Willinsky RA, Harper W, Wallace MC. Cerebral cavernous malformations: Natural history and prognosis after clinical deterioration with or without hemorrhage. J Neurosurg 1997;87:190-7.

9. Hyodo A, Yanaka K, Higuchi O, Tomono Y, Nose T. Giant interdural cavernous hemangioma at the convexity. Case illustration. J Neurosurg 2000;92:503.

10. Sansone ME, Liwnicz BH, Mandybur TI. Giant pituitary cavernous hemangioma: Case report. J Neurosurg 1980;53:124-6.

11. Tokuda Y, Uozumi T, Sakoda K, Yamada K, Yamanaka M, Nomura S, et al. Giant congenital capillary hemangioma of pericranium - Case report. Neurol Med Chir (Tokyo) 1990;30:1029-33.

12. Tüzün Y, Kayaoglu CR, Takçi E, Kadioglu HH, Suma S, Oztürk M, et al. Giant cavernous hemangioma of the scalp. Zentralbl Neurochir 1998;59:274-7.

13. Zabramski JM, Wascher TM, Spetzler RF, Johnson B, Golfinos J, Drayer BP, et al. The natural history of familial cavernous malformations: Results of an ongoing study. J Neurosurg 1994;80:422-32.

14. Abla AA, Lekovic GP, Turner JD, de Oliveira JG, Porter R,
Spetzler RF. Advances in the treatment and outcome of brainstem cavernous malformation surgery: A single-center case series of 300 surgically treated patients. Neurosurgery 2011;68:403-14.

15. Linsler S, Oertel J. Endoscopic endonasal transclival resection of a brainstem cavernoma: A detailed account of our technique and comparison with the literature. World Neurosurg 2015;84:2064-71.

This is an open access article distributed under the terms of the Creative Commons Attribution-NonCommercial-ShareAlike 3.0 License, which allows others to remix, tweak, and build upon the work non-commercially, as long as the author is credited and the new creations are licensed under the identical terms.

\begin{tabular}{|l|l|}
\hline \multicolumn{2}{|c|}{ Access this article online } \\
\hline Quick Response Code: & Website: \\
\hline & www.ruralneuropractice.com \\
\hline & \\
\hline
\end{tabular}

How to cite this article: Linsler S. Giant cavernous malformations. J Neurosci Rural Pract 2016;7:197-8. 